\title{
ICT Action School Development at Helen Parkhurst Dalton School, part II
}

\section{ICT Ação em desenvolvimento na Escola Helen Parkhurst Dalton, parte II}

\begin{abstract}
The paper presents the progress of the action plan for improvement of the ICT usage at the Helen Parkhurst Dalton School for secondary education. At the start of the action period in 2007 the ICT-usage in education was assessed through an review performed by a group of European inspectors. This an review performed by a group of European inspectors. This assessment formed the basis for a continuous development in the school for promoting and improving the usage of ICT. This was done by addressing the observed weaknesses with specia measures, and continuing the action plans which were already put in place. For four main points of criticism the following measures were taken: The coherence in the ICT use was improved by appointing school wide operating coordinators. The use of ICT in teaching was encouraged by offering a variety of teache training and dedicated workshops. The measurement of gains in learner achievement through ICT use was addressed by a comparative study on the effects of ICT in international learners collaboration. The perspective on new ICT developments in ICT and pedagogy was broadened by purchasing new equipment as interactive white boards, laptop trolleys and other digital devices and realizing new ICT-laboratories. One year after the inspectorates assessment new plans arose. The learship the schooles assessizen the school has organized a so called 'scenario debate, aimed at addressing the near future of the school. In this debate the view on education has been renewed in relation to the organizational aspects. One of the outcomes of the debate was the awarenes of the growing role of ICT. So plans for the near future have been set up. This paper is the second contribution in a row in order to describe action based school development.

Keywords: ICT use. Secondary Education. ICT quality indicators. Pedagogy. Infrastructure. Action plan.
\end{abstract}

Resumo: O trabalho apresenta a evolução do plano de ação para melhoria da utilização das TIC na escola Helen Parkhurst Dalton, no ensino secundário. No início do período de ação, em 2007, o uso de TIC na educação foi avaliado através de uma revisão realizada por um grupo de inspetores europeus. Essa avaliação serviu de base para um plano de desenvolvims. Essa contínac serviu de base para um plano de desenvolvimento contínuo na escola, para promover e melhorar a utilização das TIC. Isso foi feito para resolver os pontos fracos observados, com medidas especiais, e continuar os planos de ação que já haviam sido postos em prática. Em vista de quatro pontos críticos observados, foram tomadas as seguintes medidas: a coerência na utilização das TIC foi melhorada, em nível operacional com a nomeação de coordenadores de escola; a utilização das TIC no ensino foi incentivada ao ser oferecida uma variedade de workshops dedicados à formação de professores; o acompanhamento dos níveis de desempenho dos alunos com o uso das TIC foi abordado por um estudo comparativo em colaboração com estudantes internacionais; a perspectiva de novos desenvolvimentos das TIC, no âmbito do domínio das tecnologias e da pedagogia, foi ampliada através da aquisição de novos equipamentos, pos equipamentros, carrinhos para laptops écutros dispositivos digitais, além da criação de novos laboratórios de informática educacional. Um ano após surgimento do a organização de um "debate cenário", pelos lideres escolares, visando abordar o futuro próximo da escola. Nesse debate, a opinião sobre a educação foi renovada em relação aos aspectos organizacionais. Um dos resultados do debate foi a conscientização do papel crescente das TIC. Assim, planos para o futuro próximo da escola foram estabelecidos. Este documento é a segunda contribuição consecutiva, a fim de descrever uma ação baseada no desenvolvimento escolar.

Palavras-chave: Utilização das TIC. Ensino Secundário. Indicadores de qualidade em TIC. Pedagogia. Infra-estrutura. Plano de ação.

HOGENBIRK, Pieter; BRAAK, Peter van de. ICT Action School Development at Helen Parkhurst Dalton School: part II. Informática na Educação: teoria \& prática, Porto Alegre v. 12, n. 1, p. 25-30, jan./jun. 2009.

\author{
Pieter Hogenbirk \\ Helen Parkhurst Dalton School
}

Peter van de Braak

Helen Parkhurst Dalton School

\section{I ntroduction}

n September 2007 an assessment on ICT in education took place at the Helen $\mathrm{Pa}$ rkhurst Dalton School in the Netherlands through an inspectorates visit, by using the European Framework for the Evaluation of ICT in Education (HOGENBIRK; BRAAK, 2008). This framework is developed as part of the P2V-project, the part in which European inspectorates collaborate. The framework has been tested afterwards in several countries: Lithuania, Spain, Scotland, France and Sweden. The results were discussed in a joint meeting in September 2008 leading to a final report on the project (OEL, 2008).

After the visit the Helen Parkhurst Dalton School continued its development in using ICT to improve the educational process. In the paper we will describe the actions performed in the school year 2007-2008 and in more detail the organisation and results of the debate on the future of the school, carried out in the fall of 2008.

It is the ambition of the authors of this paper to report on a yearly base on the progress made in the school, since September 2007. 


\section{The Helen Parkhurst Dalton School}

In order to understand the developments a short characterization of the school is presented and a summary of the assessment is given.

\subsection{Brief Description of the School}

Helen Parkhurst (see figure 1 for an artist impression of the school) is a school for general secondary education for students in the age of 12 up till 18 years in the vmbo-t, havo and vwo streams, all general secondary education aimed at respectively intermediate and higher vocational education and university. The school concept is based on the Dalton principle. This means that the education is based on three principles: (1) responsibility and accountability, (2) independence and reflection and (3) relationship and collaboration. In daily practice these principles are translated into the following. The objectives for 6 (young students) to 12 weeks (older students) are fixed through so called "curriculum lines" by the teachers in the different subjects. But the order of activities, pace and to some extent the way how to reach the objectives can be determined by the students themselves, in close agreement with the teacher. Many activities are based on collaboration with other students. Important are the reflection on the different activities and the results of the learning process in relation to collaborative and planning skills.
In school year 2008-2009 the school"s population has grown to about 2050 students, divided over five departments: A, C, D, E, VP. Helen Parkhurst has one very modern building for four departments; the VP department is housed in a more informal housing. Two departments prepare for vmbo-t diplomas, one department has an emphasis on culture and arts, one department on economics and one department provides extra challenge for students that are well performing in science. There are special facilities for young top sports men and women.

Every department has its own head of department, ICT-coordinator, counsellors for pupils as well as coaches for teachers and its own team of some 40 teachers and educational assistents. There is one central ICT-coordinator.

\subsection{The Assessment by Using the European Framework for the Evaluation of ICT in Education}

For the sake of understanding the developments in ICT in school year 2007-2008 in the school the results of the assessment of September 2007 are cited in table 1 (HOGENBIRK; BRAAK, 2008). The European framework consists of three main themes: Conditions (C1 to C4), Use (U1 to U3) and Outcomes (O1). There are a number of quality areas within each theme, eight in total. Quality indicators with corresponding evidence pointers are identified within each quality area. The assessment consisted of marking the indicators with the values 0 and figures from 1 to 4 . Their meaning is:

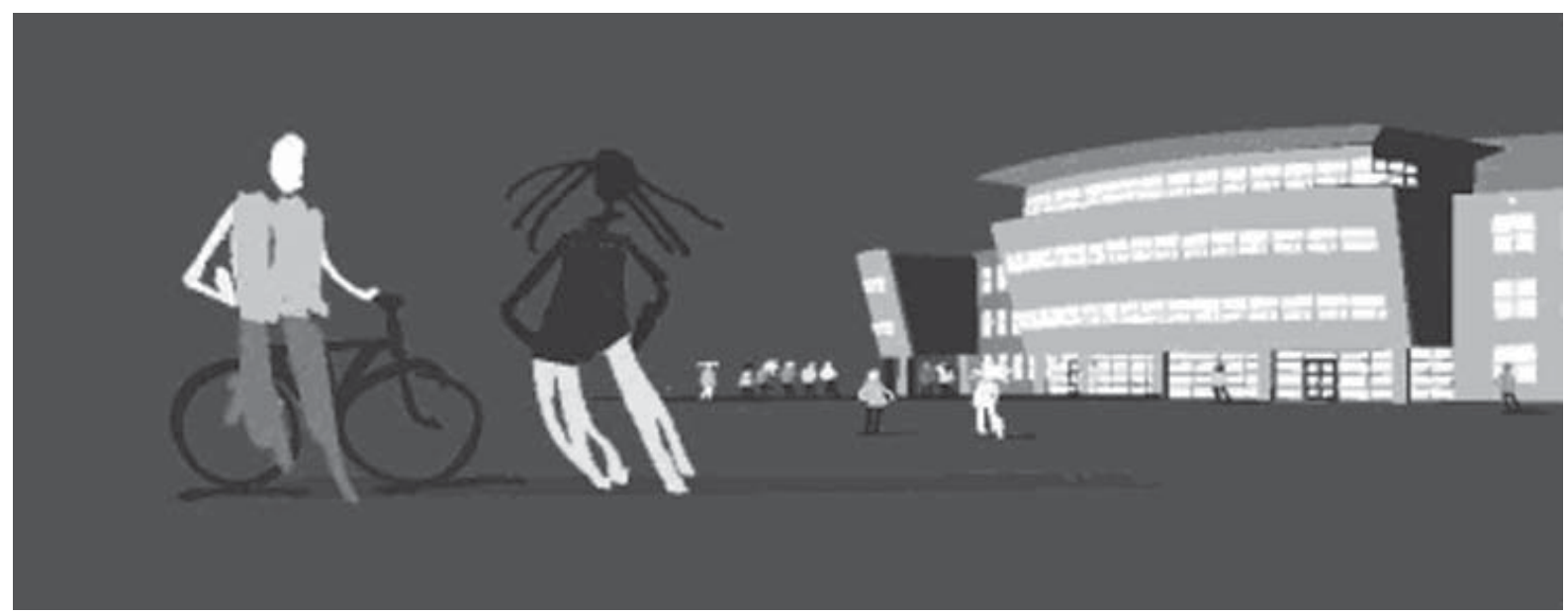

Figure 1 - Artist impression of Helen Parkhurst School 
TABLE 1 - ICT Assessment September 2007, indicators for ICT quality

\begin{tabular}{|c|c|}
\hline Leadership & Score \\
\hline C1.1There is a clear vision for the use of ICT & $0|1| 2|3| 4$ \\
\hline $\mathrm{C} 1.2$ There is a strategy to realize the vision & $0|1| 234$ \\
\hline Infrastructure and access & Score \\
\hline C2.1 The available resources reflect the needs and vision of the school & $0|1| 2 \mid 34$ \\
\hline C2.2 The deployment of ICT resources enables efficient use of them & $0|1| 2|3| 4$ \\
\hline C2.3 Support systems optimize the use of ICT & $0|1| 2 \mid 34$ \\
\hline Curriculum planning & Score \\
\hline C3.1 Meeting local, regional and national requirements & $0|1| 234$ \\
\hline C3.2 Coherence, balance and consistency & $0|1| 2|3| 4$ \\
\hline C3.3 New developments in ICT and pedagogy & $0|1| 2|3| 4$ \\
\hline Quality assurance and improvement & Score \\
\hline C4.1 Review and self-evaluation of ICT policy and practice & $0|1| 234$ \\
\hline C4.2 Action planning and implementation & $0|1| 234$ \\
\hline C4.3 Action monitoring and revision & $0|1| 2|3| 4$ \\
\hline Pupil use & Score \\
\hline U1.1 Development of ICT skills & $0|1| 2 \mid 34$ \\
\hline U1.2 Enhancement of learning & $0|1| 234$ \\
\hline The teaching process & Score \\
\hline U2.1 Developing pupils' ICT capabilities & $0|1| 234$ \\
\hline U2.2 Use of ICT to enhance teaching & $0|1| \mathbf{2}|3| 4$ \\
\hline U2.3 Teaching staff competence and confidence & $0|1| 2|3| 4$ \\
\hline Administrative use & Score \\
\hline U3.1 Identifying issues impacting learning and teaching & $0|1| 234$ \\
\hline U3.2 Communication is supported. & $0|1| 2 \mid 34$ \\
\hline Impact on learning and standards & Score \\
\hline O1.1 Gains in broad learner achievement & $0|1| 2|3| 4$ \\
\hline O1.2 Effects of ICT use on pupil attainment & $\mathbf{0}|1| 2|3| 4$ \\
\hline
\end{tabular}


0 . No evidence available or not relevant.

1. Bad There is hardly any positive evidence for a particular indicator.

2. Insufficient There is not enough positive evidence for a particular indicator.

3. Sufficient There is enough positive evidence for a particular indicator but

improvement is possible.

4. Good Most or all evidence for a particular indicator is positive.

In the written report (OEL et al., 2008) the main points of criticism were:

- a lack of variety of equipment and resources;

- a limited usage of subject specific ICTapplications and hardly any use in international collaborative projects;

- an informal and not very explicit relationship between pedagogical vision and the implementation of ICT;

- a lack of awareness from the teachers of special ICT resources, specific applications, new pedagogical features for ICT use within their subjects and ICT based assessments and testing;

- the absence of a general coordination on the ICT-curriculum;

- a lack of coherence in the use of the Digital Learning Environment;

- a general lack of coherence between departments in their ICT policy and planning;

- no systematic reflection, review or evaluation on the ICT plans on one hand and on the outcome of ICT use on the other hand.

The assessment procedure and the framework were discussed in a final meeting of European Inspectors in September 2008 in Brussels. The major findings are to be found at the site of the P2V project (SALIE, 2008).

\section{Developments in school-year 2007-2008}

Helen Parkhurst continued after the assessment to carry out the special action plans for the running school year. In short the following objectives were realized in school-year 20072008:
- More infrastructure available; in September 2008 the following was realised:

- wireless network

- laptop trolleys (now 8 with 140 laptops)

- 395 fixed computers: computer ratio: 1

to 3.8

- some 220 computers for teachers

- some 10 interactive whiteboards

- Increase of teacher training by a system of voluntary vouchers;

- Supporting and establishing good ICTpractices by participating in the national Grassroots project;

- Developing a research project on ICT effectiveness in international collaborative projects;

- Newly built studios for music and art with all kinds of digital equipment;

- Further development of the Digital Learning Environment.

The coherence between the department was addressed by co-ordinated action plans. In the spring of 2008 Helen Parkhurst Dalton School has evaluated itself by means of the so-called 'i-score rating', a new national initiative. This rating system was set up by the Dutch Teachers Union of Informatics \& Information Technology in close co-operation with the Dutch inspectorate and on the basis of the framework mentioned. In order to determine the i-score a website has been set up, where participants can fill in a questionnaire. A school then got log in codes for teachers and students, and they are asks to give a reliable image of the ICT situation in their school. On that basis the system assigns a rating of $1-5$ stars.

Helen Parkhurst was considered to "earn" a 4 star rating. Every year the score has to be updated in order to keep it tenable.

\section{Developments in school-year 2008-2009}

At the end of the course of 2007-2008 leading teachers and deputies in the school had to develop in collaboration with their specialist colleagues a so called "year action plan". This is the rule for the school as a whole, for every single department and also for every school wide theme, such as pupils care, (in service) teacher training, quality assurance and ICT. We will briefly describe the overall 
core issues to be addressed in the school year 2008-2009 and go into more detail for the plans for ICT.

\subsection{Key Issues for School Development}

On the basis of several interviews with all personal, with the students parliament and with the council of parents five key issues for development of the education in the school were defined and elaborated on. These were:

- Revitalising the Dalton identity

- further development of pupils-coaching and skills development in mentor groups

- Improving the coherence between departments by common working gatherings

- Further development of personal competences

- Extending the use of ICT and setting up a system for international projects

On top of these key elements for school innovation a so called "Scenario debate" was set up. The school faces some luxury problems. Because of the growth of the number of students the internal division of classes over the departments was not well-balanced any more. But this division over departments was well thought of and based on firm pedagogical starting points. So we could not debate on the organisational structure without discussing the pedagogical values shared among the personal. At the time this paper has to be submitted the "scenario debate" has provided a series of proposals for improving the quality of education by changing some organisational aspects, but also rethinking the Dalton values of the school. In that the debate connected the practical issues of the departments to the basic issue of revitalising the Dalton identity. For the sake of describing the developments in ICT it is important that one of the core elements that came out of the scenario debate was the importance of ICT and the use of it in coaching students and in subject didactics.

\subsection{The Running Action Plan for ICT}

In the action plan for ICT for the schoolyear 2008-2009 the following elements are brought up:

- Further and advanced educational use, p.e.

- web quests for modern languages
- more assignments on the DLE (Digital learning Environment)

- experiencing the digital studios

- Pilots on digital examinations

- Setting up a web portal for more involvement of parents

- Use of ICT for learners tracking

- A next round of vouchers for voluntary teacher training

- The introduction of netbooks for all teachers

The current situation (J anuary 1,2009 ) is:

- Some subject teachers in some departments have stored their learners assignments in the DLE

- The foreign language English is taught merely by materials on the DLE

- Operational plans are written for implementation of

- a system for learners tracking

- a programme for cultural activities in lower secondary, using the studios

- the web portal

- the intranet

- the introduction of netbooks for all teachers, completed with a risk analysis

- One pilot on digital examinations in Science is started

- Vouchers for voluntary teacher training are organised and two are organised

- The council of parents has provides budget for grassroots for improving teaching methods

- The research project on ICT effectiveness in international collaborative projects has been performed; the results were not very encouraging, because of practical problems in the international collaboration. A new project will start up and try to establish better conditions for better results.

From the beginning of 2009 the Helen Parkhurst will become a so called "Innovative School" in the Partners for Learning Program of Microsoft .

\subsection{The Emerging Vision on ICT in the Near Future}

As a result of the "scenario debate" there was a lot of emphasis on ICT and making the use of it profitable to achieve goals which were considered as basic or important. In short the following ambitions were formulated:

- (Parts of) the curriculum are fully organi- 
sed through ICT

- An ICT skills development line for students will be available

- There will be full use of ICT for reflection, portfolios and learners tracking

- ICT is widely used in examinations and tests

- Laptops/netbooks for all teachers are in full operational use

- Full transparency is reached by completion of the web portal and the intranet

- The intention is made to develop a business model for netbooks for all students

\section{Conclusion and Further Work}

The assessment of the group of inspectors using the European framework has given the Helen Parkhurst a chance to evaluate the ICT situation, educational and technical. This was at a moment in time where many decisions had to be made and where the course has to be set for the following periods. The current action plans have addressed the findings of the inspectors investigation and also reflect the direction of development the school has chosen.

The main points of criticism were addressed by concrete measures.

A variety of equipment was purchased; workshops on the educational use of ICT were organized; teachers were stimulated to use ICT in all kinds of ways; the Digital Learning Environment is promoted, however still a bit reluctant; the coherence between departments in their ICT policy and planning is improved; as systematic reflection, review or evaluation on the ICT plans is in due course.

According to the way the "Scenario debate" has had its output, the role of ICT is without questioning. Therefore the use of ICT will be extended the coming years and play a major role in revitalizing the Dalton vision.

Looking back at the assessment through the inspectorates framework we conclude that the following indicators have improved:

- C3.2, the coherence between ICT development has increased

- C3.3, new developments have been investigated and promoted

- C4.3, action monitoring is in place by regular assessments

- U2.2, the enhancement of teaching is underway, but needs to be improved

- 01.1 and 1.2, some attempts have been made to measure the impact if ICT but this is still a very difficult indicator too meet.

By this action research and by the 'scenario debate' which has been organized, we hope to improve education both in quality and learning outcome.

\section{References}

HOGENBIRK, P.; BRAAK, P. van de. ICT Action School Development on the Basis of an Inspectorates Assessment. Malaysia: LYICT, 2008.

OEL, B.J. van et al. P2V Project: Using the European Framework for the Evaluation of ICT in Education, to be published at the end of 2008.

SALIE, L. Report on Inspectors' workshop in Brussels: final meeting. 2008. Avaiable: <http://insight.eun. org/ww/en/pub/insight/policy/peer_reviews/sici_workshop_brussels.htm> Acessed: 13 dez. 2008.

Recebido em janeiro de 2009.

Aprovado para publicação em abril de 2009

Pieter Hogenbirk

Helen Parkhurst Dalton School, The Netherlands - p.hogenbirk@helenpark.nl 